\title{
Regulation of tracheal antimicrobial peptide gene expression in airway epithelial cells of cattle
}

\author{
Khaled Taha-Abdelaziz ${ }^{1,2}$, Leanna Wyer ${ }^{1}$, Lesley Berghuis ${ }^{1}$, Laura L. Bassel ${ }^{1}$, Mary Ellen Clark \\ and Jeff L. Caswell ${ }^{1 *}$ (D)
}

\begin{abstract}
$\beta$-defensins are an important element of the mucosal innate immune response against bacterial pathogens. Tracheal antimicrobial peptide (TAP) has microbicidal activity against the bacteria that cause bovine respiratory disease, and its expression in tracheal epithelial cells is upregulated by bacterial products including lipopolysaccharide (LPS, a TLR4 agonist), Pam3CSK4 (an agonist of Toll-like receptor 2/1), and interleukin (IL)-17A. The objectives of this study were to identify the signalling pathway by which LPS, Pam3CSK4 and IL-17A induce TAP gene expression, and to determine the effect of glucocorticoid as a model of stress on this epithelial innate immune response. In primary cultures of bovine tracheal epithelial cells (bTEC), LPS, Pam3CSK4 and IL-17A each stimulated TAP gene expression. This effect was abrogated by caffeic acid phenylester (CAPE), an inhibitor of NF-KB. Similarly, western analysis showed that LPS, Pam3CSK4 and IL-17A each induced translocation of NF-KB p65 from the cytoplasm to the nucleus, but pre-treatment with CAPE inhibited this response. Finally, pre-treatment of bTEC with the glucocorticoid dexamethasone abolished the stimulatory effect of LPS, Pam3CSK4 and IL-17A on upregulation of TAP gene expression. These findings indicate that NF-KB activation is necessary for induction of TAP gene expression by LPS (a TLR4 agonist), Pam3CSK4 (a TLR2/1 agonist), or IL-17A. Furthermore, this stimulatory response is inhibited by glucocorticoid, suggesting this as one mechanism by which stress increases the risk of bacterial pneumonia. These findings have implications for understanding the pathogenesis of stress-associated bacterial pneumonia, and for developing methods to stimulate innate immune responses in the respiratory tract of cattle.
\end{abstract}

\section{Introduction}

Tracheal antimicrobial peptide (TAP) is a $\beta$-defensin produced by airway epithelial cells that has direct bactericidal activity against bacterial pathogens including those that cause respiratory disease in cattle [1-3]. Other defensins also have immunomodulatory functions that may contribute to respiratory health $[4,5]$ although such a role has not been reported for TAP. TAP gene expression is highly upregulated following exposure to inhaled bacteria or LPS. Thus, activation of TAP gene expression by Gram negative bacteria such as Mannheimia

\footnotetext{
*Correspondence: jcaswell@uoguelph.ca

1 Department of Pathobiology, University of Guelph, Guelph, ON, Canada Full list of author information is available at the end of the article
}

haemolytica represents an inducible mechanism of innate defence in the respiratory tract of cattle.

Risk factors for bovine respiratory disease are widely recognized and include the stresses of weaning, transportation, castration and inclement weather conditions, as well as viral infections, all of which occur at the time calves are removed from their dams and enter feedlots. These predisposing factors interfere with innate immune responses, alter bacterial populations in the nasal cavity, and are associated with increased number of bacteria reaching the lung [6]. Tracheal antimicrobial peptide is among the innate respiratory defences that are dysregulated by the effects of stress and glucocorticoid [7], viral infection including bovine viral diarrhea virus [8], and pollutants such as vanadium oxide in diesel exhaust [9]. Specifically, glucocorticoid and bovine viral diarrhea 
viral infection do not affect baseline expression of TAP in bTEC, but suppress the stimulatory effect of LPS both in vitro and in vivo. These findings suggest a mechanism by which stress and viral infection suppress innate defences in the respiratory tract and predispose to bacterial pneumonia.

Knowledge of these specific mechanisms by which respiratory defences fail suggests an opportunity to stimulate innate immune responses in the respiratory tract during times of susceptibility to pneumonia. The observation of a somewhat delayed effect of LPS, with peak effect at $16 \mathrm{~h}$ of stimulation [7, 10], prompted us to evaluate other agonists. We recently identified earlier induction of TAP gene expression in primary cultures of bovine tracheal epithelial cells (bTEC) following stimulation with agonists of TLR2/1 (Pam3CSK4) and IL-17A receptor (IL-17A) [10]. Greater understanding of the mechanisms of these innate immune responses may be of value not only for understanding pathogenesis, but also for development of novel methods to prevent disease. Thus, the objectives of this study were to identify the signalling pathway by which LPS, Pam3CSK4, and IL17A upregulate TAP gene expression, and to determine whether this stimulatory pathway is similarly inhibited by glucocorticoid.

\section{Materials and methods}

\section{Cell culture}

Primary cultures of bovine tracheal epithelial cells (bTEC) were established and stimulated with agonists as previously described [10]. Briefly, bTEC were obtained from healthy market-weight beef cattle at slaughter, and a different donor was used for each experiment. Cells were grown to $80-90 \%$ confluency on collagen-coated plates in supplemented Dulbecco's modified Eagle's and Ham's F-12 medium (DMEM/F12) containing 5\% fetal bovine serum. Triplicate cell cultures supplemented with DMEM/F12 without serum were unstimulated, or stimulated with $0.1 \mu \mathrm{g} / \mathrm{mL}$ LPS (Sigma Aldrich, MO, USA, L9143), $1 \mu \mathrm{g} / \mathrm{mL}$ Pam3CSK4 (Invivogen, San Diego, CA, USA, t1rl-pms), or $316 \mathrm{ng} / \mathrm{mL}$ IL-17A (Kingfisher Biotech, St. Paul, MN, USA, RP0056B-005) for $16 \mathrm{~h}$. The doses and time were optimized in a previous study [10].

To investigate the mechanism by which LPS, Pam3CSK4 and IL-17A induce TAP gene expression, bTEC were pre-treated for $2 \mathrm{~h}$ with $0.5-10 \mu \mathrm{M}$ caffeic acid phenylester (CAPE; Calbiochem, San Diego, USA), an inhibitor of NF- $\mathrm{kB}$ signalling, before stimulation with LPS, Pam3CSK4 or IL-17A as described above. To investigate the role of c-Jun $\mathrm{N}$-terminal kinase (JNK) in TLR2/1-mediated signalling, cells were treated for $2 \mathrm{~h}$ with 10-25 $\mu \mathrm{M}$ of the JNK inhibitor SP600125 (SigmaAldrich, USA), prior to stimulation with Pam3CSK4.
The findings were confirmed by repeating the study with bTEC from a different animal.

To measure the effect of corticosteroid on inducible expression of TAP, bTEC were treated in triplicate with $10^{-6} \mathrm{M}$ dexamethasone sodium phosphate (Vétoquinol, Lavaltrie, QC, Canada) in supplemented DMEM/F12 for $24 \mathrm{~h}$ before 16-h stimulation with agonists (a total of $40 \mathrm{~h}$ of dexamethasone treatment). This dose and time had been optimized in a previous study [7]. The findings were confirmed by repeating the study with bTEC from a different animal. To measure cell viability and cytotoxicity of the treatments, lactate dehydrogenase (LDH) activity was measured in supernatants collected at the end of the experiments, following the manufacturer's instructions (Cytotoxicity Detection Kit, Roche Diagnostics, Mannheim, Germany).

RNA extraction and cDNA synthesis were carried out as previously described [10]. Briefly, total RNA was extracted (RNEasy ${ }^{\circledR}$ Mini kit, Qiagen), treated with DNase I, eluted in RNase-free water, and 100 ng of total RNA was reverse transcribed to cDNA using Superscript III. Real-time reverse transcription quantitative PCR was conducted using LightCycler 480 technology (Roche Diagnostics) to quantify relative gene expression between stimulated and non-stimulated as well as pre-treated bTEC. Gene expression of TAP was measured relative to the reference gene glyceraldehyde-3-phosphate dehydrogenase (GAPDH) as previously described [10]. Threshold cycles for both TAP and the reference gene (GAPDH) calculated by the LightCycler 480 software (Roche Diagnostics) were normalized to a calibrator, and data of technical duplicate samples were averaged.

\section{Western analysis of NF-KB p65}

Localization of NF- $\mathrm{kB}$ p65 to the cytoplasm and nucleus was analyzed by western blot. For preparation of cytosolic and nuclear protein fractions, stimulated bTEC were washed with cold PBS and lysed as described [11, 12]. Cells were harvested by scraping into lysis buffer containing $10 \mathrm{mM}$ HEPES $\mathrm{pH} 7.9,1.5 \mathrm{mM} \mathrm{MgCl} 2,10 \mathrm{mM}$ $\mathrm{KCl}, 0.25 \% \mathrm{v} / \mathrm{v}$ noident P-40, $0.5 \mathrm{mM}$ phenylmethylsulfonyl fluoride (PMSF), and $0.5 \mathrm{mM}$ dithiothreitol (DTT); then incubated for $20 \mathrm{~min}$ on ice. Cells were centrifuged at $12000 \times g$ for $15 \mathrm{~s}$ at $4{ }^{\circ} \mathrm{C}$ and supernatant (the cytoplasmic fraction) was collected. The remaining pellet was lysed by adding $15 \mu \mathrm{L}$ of $20 \mathrm{mM}$ HEPES $\mathrm{pH}$ 7.9, $1.5 \mathrm{mM}$ $\mathrm{MgCl}_{2}, 420 \mathrm{mM} \mathrm{NaCl}, 0.5 \mathrm{mM} \mathrm{DTT}, 25 \%$ v/v glycerol, and $0.5 \mathrm{mM}$ PMSF, incubating for $20 \mathrm{~min}$ on ice, then centrifuged at $12000 \times g$ for $60 \mathrm{~s}$ at $4{ }^{\circ} \mathrm{C}$. The supernatant (the nuclear fraction) was collected and $60 \mu \mathrm{L}$ of $20 \mathrm{mM}$ HEPES pH 7.9, $50 \mathrm{mM} \mathrm{KCl}, 0.5 \mathrm{mM}$ DTT, $0.2 \mathrm{mM}$ EDTA, and $0.5 \mathrm{mM}$ PMSF was added. The protein concentrations of the cytoplasmic and nuclear extracts 
were measured by spectrophotometry (Nanodrop 2000, Thermo Scientific, Wilmington, DE, USA).

Samples of nuclear or cytoplasmic extracts $(20 \mu \mathrm{g}$ protein) or positive control NF-kB p65-transfected cell lysate (10 $\mu$ g protein; Santa Cruz Biotechnology, USA) were separated by $10 \%$ SDS-PAGE at $120 \mathrm{~V}$ for $2 \mathrm{~h}$ and then blotted on a PVDF membrane at $90 \mathrm{~V}$ for $1 \mathrm{~h}$. The amount of protein loaded was initially optimized based on Coomassie blue-stained SDS-PAGE. Membranes were blocked by incubation with 5\% skim milk in Tris PBS-0.1\% Tween for $2 \mathrm{~h}$ with rocking then washed several times for $30 \mathrm{~min}$, followed by incubation with rabbit anti-NF-kB p65 antibody (1:200, Santa Cruz Biotechnology, USA) for $2 \mathrm{~h}$ with rocking at room temperature. Membranes were washed for $30 \mathrm{~min}$ before incubation with goat anti-rabbit HRP (1:4000; Dako, Denmark) for 30 min with rocking at room temperature. Membranes were washed and then incubated with enhanced chemiluminescence reagent for $1 \mathrm{~min}$. The bands were visualized and photographed.

\section{Statistical analysis}

Real-time RT-PCR data (normalized ratios of TAP:GAPDH) were log-transformed if needed to normalize the distribution, then analyzed by one- or two-way ANOVA test (Graphpad prism V5.0, Graphpad software, San Diego, CA, USA), and considered significant at $P<0.05$. Graphical data are presented as mean \pm standard error of the mean (SEM).

\section{Results}

Role of NF-KB and JNK signalling in inducible TAP gene expression in bTEC

Treatment of bTEC with LPS, Pam3CSK4, or IL-17A resulted in significant induction of TAP gene expression compared to non-stimulated cells. Pre-treatment with CAPE (an inhibitor of NF- $\mathrm{B}$ activation) suppressed this stimulatory effect for all three agonists: LPS, Pam3CSK4, and IL-17A (Figure 1; $P<0.0001$ for each agonist, one-way ANOVA with Tukey's post-test). At maximal effect using $8 \mu \mathrm{M}$ CAPE, TAP gene expression in LPS-treated cells was not significantly different from unstimulated cells (Figure 1A). Treatment of bTEC with 6-10 $\mu \mathrm{M}$ CAPE resulted in dose-dependent inhibition of Pam3CSK4-induced TAP gene expression (Figure 1B), with $84 \%$ reduction in TAP gene expression using $10 \mu \mathrm{M}$ CAPE. Treatment with $10 \mu \mathrm{M}$ CAPE reduced IL-17A-induced TAP gene expression by $55 \%$ (Figure $1 \mathrm{C}$ ).

Cytoplasmic and nuclear NF- $\mathrm{B}$ p65 were examined by western blot analysis of bTEC to further confirm the
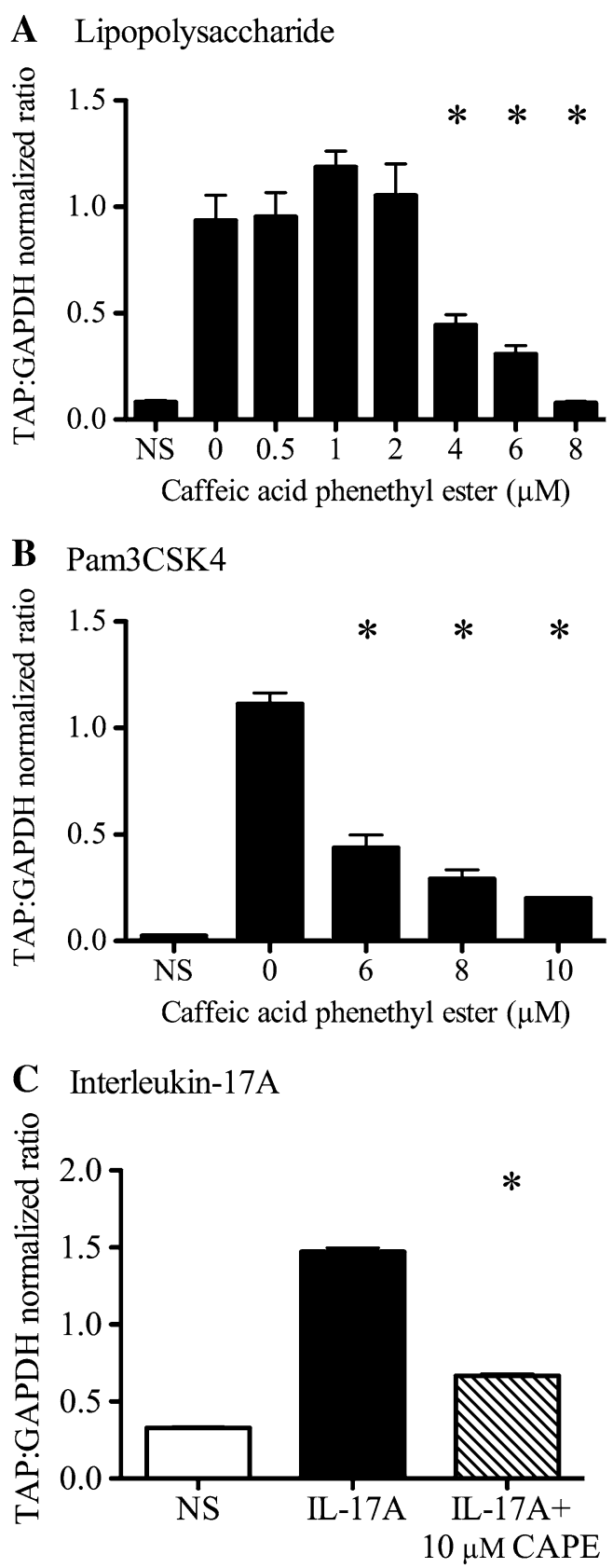

Figure 1 Effect of the NF-kB inhibitor caffeic acid phenylester (CAPE) on induction of TAP gene expression by LPS, Pam3CSK4 and IL-17A. Stimulation of bovine tracheal epithelial cells (bTEC) with $0.1 \mu \mathrm{g} / \mathrm{mL}$ LPS (panel A), $1 \mu \mathrm{g} / \mathrm{mL}$ Pam3CSK4 (panel B), or $316 \mathrm{ng} / \mathrm{mL}$ IL-17A (panel C) induced significantly greater TAP gene expression than in non-stimulated cells (NS). Pre-treatment with CAPE for $2 \mathrm{~h}$ before stimulation inhibited each of these responses. Asterisks indicate significant effects of CAPE treatment compared to no CAPE, $P<0.0001$, one-way ANOVA. The data are mean \pm SEM of technical triplicates, and the findings were similar when the experiments were repeated using cells from different animals. 
involvement of NF- $\mathrm{kB}$ in induction of TAP gene expression by LPS, Pam3CSK4, or IL-17A. In unstimulated cells, NF-kB p65 was detected in the cytoplasmic but not in the nuclear fractions (Figure 2). In bTEC that were stimulated for $16 \mathrm{~h}$ with $0.1 \mu \mathrm{g} / \mathrm{mL}$ LPS, NF-kB p65 was detected in both the nuclear and the cytoplasmic fractions. In contrast, in bTEC treated with $10 \mu \mathrm{M}$ CAPE prior to stimulation with LPS, NF-kB p65 was detected only in the cytoplasmic fractions (Figure 2A). Similarly, in bTEC stimulated for $16 \mathrm{~h}$ with $1 \mu \mathrm{g} / \mathrm{mL}$ Pam3CSK4, NF- $\mathrm{kB}$ p65 was detected in both the nuclear and the cytoplasmic fractions, whereas NF- $\mathrm{kB}$ p 65 was detected only in the cytoplasmic fractions in bTEC treated with $10 \mu \mathrm{M}$ CAPE prior to stimulation with Pam3CSK4 (Figure 2B). Finally, NF- $\mathrm{kB}$ p 65 was detected in the nuclear fraction of bTEC

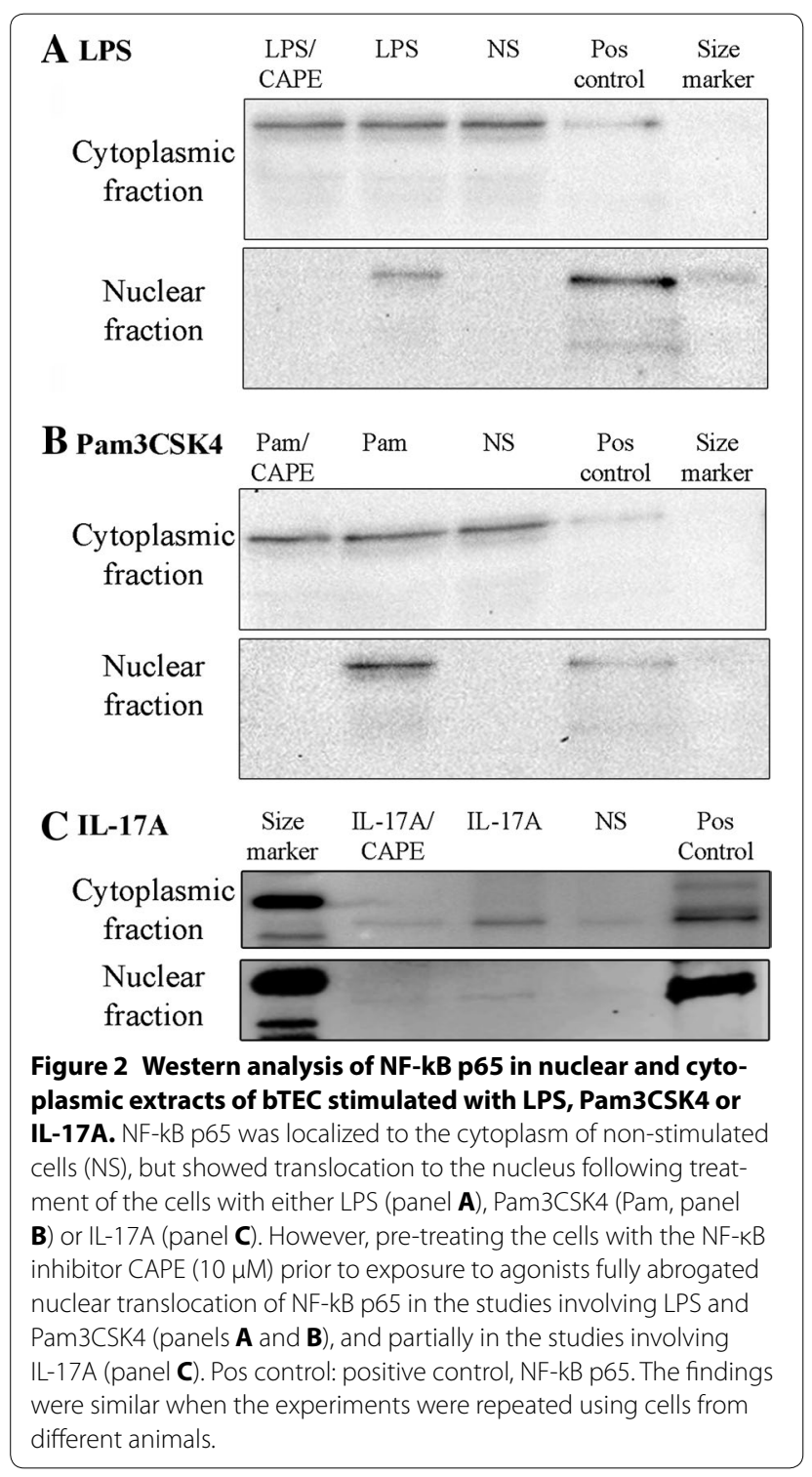

stimulated for $16 \mathrm{~h}$ with $316 \mathrm{ng} / \mathrm{mL}$ IL-17A, whereas treatment with $10 \mu \mathrm{M}$ CAPE prior to stimulation with IL-17A partially inhibited this effect (Figure 2C). These findings show that LPS, Pam3CSK4, or IL-17A induce translocation of NF- $\mathrm{KB}$ p 65 from the cytoplasm to the nucleus, with inhibition of this effect by CAPE.

The role of JNK in Pam3CSK4-induced TAP gene expression was evaluated using the JNK inhibitor SP600125. Treatment of bTEC with different doses (10$25 \mu \mathrm{M})$ of SP600125 had no significant effect $(P>0.05$, one-way ANOVA) on Pam3CSK4-induced stimulation of TAP gene expression (Figure 3).

RT-PCR crossing points of GAPDH mRNA were not affected by treatment with LPS, Pam3CSK4, IL-17A, CAPE or SP600125. Based on measurement of LDH in cell culture supernatants, cell viability was greater than 98\% following exposure to either CAPE or SP600125, and morphologic evidence of cytotoxicity was not observed.

\section{Effect of corticosteroids on upregulation of TAP gene expression}

LPS, Pam3CSK4 and IL-17A each significantly $(P<0.05)$ induced TAP gene expression in bTEC compared to the non-stimulated controls. Pre-treatment with dexamethasone abrogated the stimulatory effect of either LPS, Pam3CSK4 or IL-17A ( $P<0.05$, 1-way ANOVA), to levels equal to that of the non-stimulated cells (Figure 4). LDH release (cytotoxicity) was not observed as a consequence of treatment with LPS, Pam3SCK4, IL-17A, or dexamethasone (Figure 4). The findings were not significantly different when agonists were added to medium containing $5 \%$ fetal bovine serum, rather than the serum-free medium used above (data not shown).

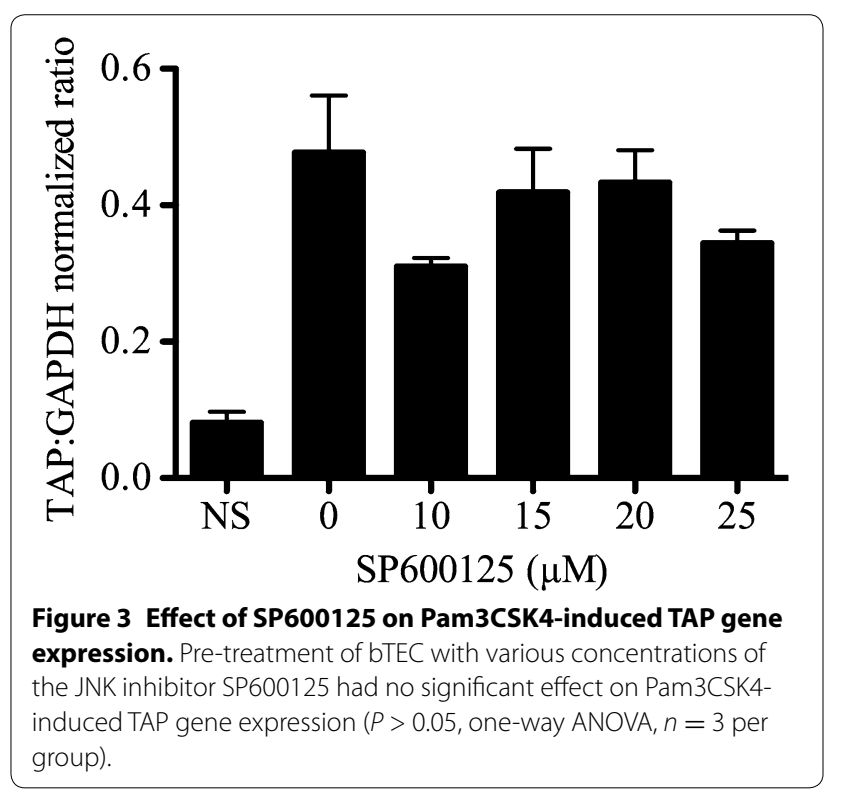




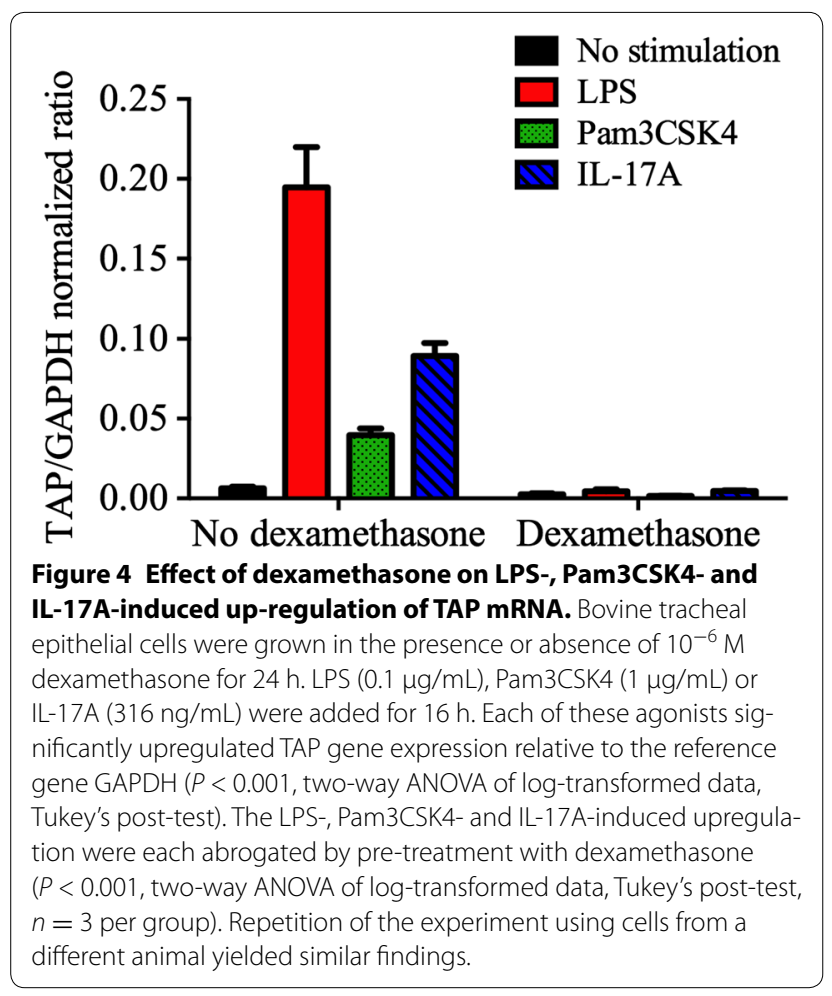

\section{Discussion}

Innate immune responses are normally effective in protecting the lung, but are susceptible to failure as a result of stress and viral infection. Thus, strategies to restore these responses may be useful for disease prevention. The agonists LPS, Pam3CSK4, and IL-17A induce rapid and strong induction of TAP gene expression in bTEC. The present study indicates NF- $\mathrm{KB}$ signalling as a necessary pathway for this effect. However, the stimulatory effects of LPS, Pam3CSK4, and IL-17A on TAP gene expression were all inhibited by dexamethasone treatment, showing that the suppressive effects of glucocorticoids and possibly of stress on this epithelial innate immune response are not specific for one pathway of cell activation.

CAPE is an inhibitor of $\mathrm{IkB} \alpha$ phosphorylation and of subsequent activation and nuclear translocation of NF-kB $[13,14]$. Treatment of bTEC with CAPE resulted in abrogation of the stimulatory effects of LPS and Pam3CSK4, indicating a key role for NF-kB activation in development of this innate immune response. For IL-17A, the response was not completely abolished by CAPE, suggesting a possible involvement of other signalling pathways in IL-17A-induced TAP gene expression. For example, a prior study identified a role for the transcription factor Oct-1 in phorbol myristate acetatestimulated induction of TAP gene expression in a bovine mammary epithelial cell line [15]. Thus, further studies are needed to more fully understand the regulation of IL$17 \mathrm{~A}-$ mediated induction of TAP gene expression. We considered the possibility of CAPE-induced cytotoxicity as a potential reason for reduction in TAP gene expression. However, this is excluded by the fact that expression of the reporter gene GAPDH was not similarly inhibited, LDH was not detected in supernatants, and morphologic evidence of cytotoxicity was not observed.

Western blot analysis of NF- $\mathrm{kB}$ p 65 provided an alternative experimental approach to confirm the above findings. Treatment of bTEC with LPS, Pam3CSK4, or IL-17A resulted in translocation of NF-kB p65 from cytoplasm to nucleus, indicating that the NF-kB signalling pathway is induced by these agonists. For Pam3CSK4 and LPS, this effect was completely blocked by prior treatment with CAPE, with all NF- $\mathrm{KB}$ p65 remaining in the cytoplasm. In contrast, CAPE pre-treatment reduced but did not completely abrogate NF- $\mathrm{kB}$ translocation to the nucleus in the experiments involving stimulation with IL-17A. These findings confirm the above-noted effects of CAPE on this signal transduction pathway. Earlier studies identified an NF-kB-binding site in the promoter region of the TAP gene [15], and suggested a role of NF- $k B$ in LPSinduced TAP gene expression by identifying that NF- $\mathrm{kB}$ and NF IL- 6 binding sites in the region of the TAP gene were important for gene expression based on a luciferase reporter assay [16]. The present study extends this genetic approach to confirm the importance of NF- $\mathrm{kB}$ using two functional assays in the target cells of interest, and further identifies an important role of NF- $\mathrm{kB}$ in mediating the stimulatory effect of Pam3CSK4 and IL-17A.

The JNK signalling pathway was investigated as an alternative pathway for Pam3CSK4-induced stimulation of TAP gene expression, because this pathway is necessary for induction of human $\beta$-defensins -2 and -3 by pathogenic bacteria and for TLR2/1-induced production of proinflammatory cytokines [17-19]. However, the JNK inhibitor had no significant effect on Pam3CSK4-induced TAP gene expression, implying that this pathway is not necessary for this effect. Overall, these findings are consistent with a necessary role for NF-kB in upregulation of TAP gene expression by LPS, Pam3CSK4, or IL-17A, and suggest that strategies to stimulate NF- $\mathrm{kB}$ signalling pathways may be of value for enhancing production of TAP by airway epithelial cells.

A second goal of the study was to investigate the impact of glucocorticoids on LPS-, Pam3CSK4- and IL-17A-mediated up-regulation of TAP gene expression, as a mechanism by which stress modulates the innate respiratory defenses. Dexamethasone had no effect on the very low constitutive level of TAP gene expression in BTEC, but inhibited the upregulation of TAP gene expression following stimulation with LPS, Pam3CSK4, or IL-17A. As above, cytotoxicity was excluded as a reason for this inhibitory effect. 
These findings indicate that the previously discovered inhibitory effects of glucocorticoid on TAP gene expression [7] are not limited to LPS stimulation acting through TLR4, but that similar inhibitory effects occur when Pam3CSK4 or IL-17A are used as agonists. Although additional work is needed to identify precise mechanisms by which dexamethasone exerts these effects, these findings clearly show that the effect is not unique to TLR4 expression or function. Instead, dexamethasone may have a more general suppressive effect on, for example, the expression of a broader range of cell surface receptors, I- $\mathrm{kB}$ kinase function, expression or stability of $\mathrm{I}-\mathrm{kB}$, or the promoter region of the TAP gene [20].

The use of primary cell cultures rather than cell lines is advantageous to ensure the findings of this study have in vivo relevance [21]. It is acknowledged that primary cultures of bTEC overlook the complex interactions that occur in vivo in the respiratory tract such as, for example, effects of glucocorticoids on leukocytes that subsequently affect epithelial cell responses. Nonetheless, this strategy is favourable as it focuses on responses of bTEC to understand the biology of these epithelial cell responses during stress and inflammation.

Together, these findings extend our knowledge of how innate immune responses of the respiratory tract are induced, and how they are susceptible to failure under conditions of glucocorticoid excess. Specifically, this study establishes NF- $\mathrm{KB}$ as a necessary mediator of LPS-, Pam3CSK4-, or IL-17A-induced upregulation of TAP gene expression, and shows that corticosteroid abrogates the immunostimulatory effects of TLR2/1, TLR4 and IL17AR. These findings have implications with respect to developing methods to restore innate immune responses in stressed cattle.

\begin{abstract}
Abbreviations
bTEC: bovine tracheal epithelial cells; CAPE: caffeic acid phenylester; DMEM/ F12: Dulbecco's modified Eagle's and Ham's F-12 medium; DTT: dithiothreitol; GAPDH: glyceraldehyde-3-phosphate dehydrogenase; L: interleukin; JNK: c-Jun N-terminal kinase; LDH: lactate dehydrogenase; LPS: lipopolysaccharide; PMSF: phenyImethylsulfonyl fluoride; SEM: standard error of the mean; TAP: tracheal antimicrobial peptide.
\end{abstract}

\section{Competing interests}

The authors declare that they have no competing interests.

\section{Author details \\ 1 Department of Pathobiology, University of Guelph, Guelph, ON, Canada. \\ 2 Department of Pathology, Faculty of Veterinary Medicine, Beni-Suef Univer- sity, Beni-Suef, Egypt.}

\section{Authors' contributions}

KTA participated in study design, carried out the experimental work on signal transduction, and helped draft the manuscript; LW performed the work on inhibition by glucocorticoid and helped draft the manuscript; LB, LLB and MEC contributed to study design and methodology; JLC conceived of the study, participated in study design and coordination, and helped draft the manuscript. All authors read and approved the final manuscript.

\section{Acknowledgements}

This work was funded by the Natural Sciences and Engineering Research Council of Canada (NSERC; RGPIN 227845, EGP 460906-13, CRDPJ 476331-14), the Beef Farmers of Ontario (13-05), and the Ontario Ministry of Agriculture and Food (UofG2013-1488).

Received: 25 November 2014 Accepted: 2 March 2016

Published online: 17 March 2016

\section{References}

1. Taha-Abdelaziz K, Perez-Casal J, Schott C, Hsiao J, Attah-Poku S, Slavic D, Caswell JL (2013) Bactericidal activity of tracheal antimicrobial peptide against respiratory pathogens of cattle. Vet Immunol Immunopathol 152:289-294

2. Lawyer C, Pai S, Watabe M, Bakir H, Eagleton L, Watabe K (1996) Effects of synthetic form of tracheal antimicrobial peptide on respiratory pathogens. J Antimicrob Chemother 37:599-604

3. Diamond G, Zasloff M, Eck H, Brasseur M, Maloy WL, Bevins CL (1991) Tracheal antimicrobial peptide, a cysteine-rich peptide from mammalian tracheal mucosa: peptide isolation and cloning of a cDNA. Proc Natl Acad Sci U S A 88:3952-3956

4. Diamond $G$, Ryan $L$ (2011) Beta-defensins: what are they really doing in the oral cavity? Oral Dis 17:628-635

5. Kohlgraf KG, Pingel LC, Dietrich DE, Brogden KA (2010) Defensins as anti-inflammatory compounds and mucosal adjuvants. Future Microbiol 5:99-113

6. Caswell JL (2014) Failure of respiratory defenses in the pathogenesis of bacterial pneumonia of cattle. Vet Pathol 51:393-409

7. Mitchell GB, Al-Haddawi MH, Clark ME, Beveridge JD, Caswell JL (2007) Effect of corticosteroids and neuropeptides on the expression of defensins in bovine tracheal epithelial cells. Infect Immun 75:1325-1334

8. Al-Haddawi M, Mitchell GB, Clark ME, Wood RD, Caswell JL (2007) Impairment of innate immune responses of airway epithelium by infection with bovine viral diarrhea virus. Vet Immunol Immunopathol 116:153-162

9. Klein-Patel ME, Diamond G, Boniotto M, Saad S, Ryan LK (2006) Inhibition of beta-defensin gene expression in airway epithelial cells by low doses of residual oil fly ash is mediated by vanadium. Toxicol Sci 92:115-125

10. Berghuis L, Abdelaziz K, Bierworth J, Wyer L, Jacob G, Karrow NA, Sharif S, Clark ME, Caswell JL (2014) Comparison of innate immune agonists for induction of tracheal antimicrobial peptide gene expression in tracheal epithelial cells of cattle. Vet Res 45:105

11. Berger N, Ben Bassat H, Klein BY, Laskov R (2007) Cytotoxicity of NFkappaB inhibitors Bay 11-7085 and caffeic acid phenethyl ester to Ramos and other human B-lymphoma cell lines. Exp Hematol 35:1495-1509

12. Jones E, Adcock IM, Ahmed BY, Punchard NA (2007) Modulation of LPS stimulated NF-kappaB mediated Nitric Oxide production by PKCepsilon and JAK2 in RAW macrophages. J Inflamm (Lond) 4:23

13. Natarajan K, Singh S, Burke TR Jr, Grunberger D, Aggarwal BB (1996) Caffeic acid phenethyl ester is a potent and specific inhibitor of activation of nuclear transcription factor NF-kappa B. Proc Natl Acad Sci U S A 93:9090-9095

14. Wang LC, Chu KH, Liang YC, Lin YL, Chiang BL (2010) Caffeic acid phenethyl ester inhibits nuclear factor-kappaB and protein kinase B signalling pathways and induces caspase-3 expression in primary human CD4+T cells. Clin Exp Immunol 160:223-232

15. Yang J, Sang Y, Meade KG, Ross C (2011) The role of oct-1 in the regulation of tracheal antimicrobial peptide (TAP) and lingual antimicrobial peptide (LAP) expression in bovine mammary epithelial cells. Immunogenetics 63:715-725

16. Diamond G, Kaiser V, Rhodes J, Russell JP, Bevins CL (2000) Transcriptional regulation of beta-defensin gene expression in tracheal epithelial cells. Infect Immun 68:113-119

17. Lin W, Ding M, Xue J, Leng W (2013) The role of TLR2/JNK/NF-kappaB pathway in amyloid beta peptide-induced inflammatory response in mouse NG108-15 neural cells. Int Immunopharmacol 17:880-884

18. Scharf S, Zahlten J, Szymanski K, Hippenstiel S, Suttorp N, N'Guessan PD (2012) Streptococcus pneumoniae induces human beta-defensin-2 and -3 in human lung epithelium. Exp Lung Res 38:100-110 
19. Scharf S, Hippenstiel S, Flieger A, Suttorp N, N'Guessan PD (2010) Induction of human beta-defensin-2 in pulmonary epithelial cells by Legionella pneumophila: involvement of TLR2 and TLR5, p38 MAPK, JNK, NF-kappaB, and AP-1. Am J Physiol Lung Cell Mol Physiol 298:L687-695
20. Scheinman Rl, Cogswell PC, Lofquist AK, Baldwin AS Jr (1995) Role of transcriptional activation of I kappa B alpha in mediation of immunosuppression by glucocorticoids. Science 270:283-286

21. FANTOM Consortium and the RIKEN PMI and CLST (DGT) (2014) A promoter-level mammalian expression atlas. Nature 507:462-470
Submit your next manuscript to BioMed Central and we will help you at every step:

- We accept pre-submission inquiries

- Our selector tool helps you to find the most relevant journal

- We provide round the clock customer support

- Convenient online submission

- Thorough peer review

- Inclusion in PubMed and all major indexing services

- Maximum visibility for your research

Submit your manuscript at www.biomedcentral.com/submit
(O) BioMed Central 